\title{
Open Access Publishing from the Legal Point of View. Why Freedom of Information Rules and Other Legal Principles Matter. Towards A New Fair Open Access Model.
}

\author{
Jiří Kolman* and Petr Kolman** \\ * Global Change Research Centre, Academy of Sciences of the Czech Republic \\ (CzechGlobe). Brno, the Czech Republic, kolman.j@czechglobe.cz, \\ http://www.czechglobe.cz/en/ contact-detail/?idk=224 \\ ${ }^{* *}$ Masaryk University: Faculty of Law. Brno, the Czech Republic, \\ Petr.Kolman@law.muni.cz, http://www.muni.cz/people/9960
}

\begin{abstract}
This article focuses on aspects that, as far as we know, have never been discussed in previous debates dealing with open access. The EU and national competition legal rules ensuring fair competition are a rather neglected aspect of open access. Another crucial topic is the unfairness of the current publication system. Why should commercial publishers be paid by publicly supported research such as EU or national research programmes? In the article a new publication model is suggested. The proposed model is trying to keep high research standards, to be fair to researchers and the public and to take into account the actual costs of the new open access model.
\end{abstract}

Keywords: open access publishing, academic knowledge, freedom of information, free access to information, public aid rules, competition law, open access journals.

Acknowledgement: The research was supported by the grant CzechGlobe - Center for Global Climate Change Impacts Studies No. CZ.1.05/1.1.00/02.0073 of the MEYS

\section{Introduction}

Discussions of open access models for publishing research results often neglect all the needs and expectations of the stakeholders (including researchers, research institutions, universities, governments, the general public and publishers). This article will first describe the main needs and expectations of the open access stakeholders respectively users of the scientific results. This is the necessary basis for the next steps in our analysis and the proposal of a new open access model.

After the identification of this model, we will discuss the current situation from a legal point of view. This will be analysed mainly from the perspective of European Union law as well as international law and principles (international treaties, customary international law). Current open access models will be analysed mainly from the legal point of view of the free access to information. Also the perspective of competition law (that is in European Union mainly regulated by EU supranational common legislation) will be discussed.

The article also proposes a new model for the publication of research results. This new model tries to ensure high research standards as well as fairness for the researchers and interested public. It will also take care of the costs of this new open access formula.

Finally, there will be some reflections and conclusions. This will include some aspects and questions that may be analysed in the future. 


\section{An Ideal Model of Open Access Means the Ideal Access to Research Results. Without a Clear Aim There Cannot Be A Clear Game.}

The first part of this section may sound banal to open access stakeholders and brining nothing new. However, articles, proposals or any text dealing with open access rules often neglect some needs of open access or unfairly privilege some needs or the interest of one group of stakeholders. The former reason might be the result of ignoring the needs of an effective publishing model, whereas the latter might result from lobbying activities supporting the interests of one group. These lobbying approaches fully comply with Robert Dahl's (1989) theory of polyarchy. Nevertheless for a legal approach it is necessary to specify the goals of the legal regulation fairly and completely without exclusion of any stakeholder's fair interests. Without clearly specified aims there cannot be a clear game.

We can conclude the analysis of an ideal model of open access by formulating the following vision that is based on the above-mentioned assumptions. The best and fairest model for publishing and providing research results provision is to provide and publish high quality research and development results in a short period after the result

In the above-mentioned vision we can distinguish the following main elements of ideal open access:

1) Fairness

2) Provision (publication) of research results

3) High quality R\&D results

4) Publication shortly after the short period for publication process after finish of the research

5) Costs for the stakeholders

1) Fairness includes legal and ethical aspects that should be always reflected when discussing reforms of access policies. A good access model should include all fair and legal aspects and not create a system that might be illegal or pushing any of stakeholders to act on the borders of the law. In the current situation, for example the practice of free peer reviewing might be disputable. Why should they conduct reviews without payments? How can society in this context ask them to take the responsibility to act honestly and really review submitted articles by applying the highest quality standards? In other professional activities it is an axiom that for conducting a good job you should be paid. The current situation could also face the critique that is in conflict with constitutional principles of many countries where it is stated that for work one should be fairly remunerated. Professional peer reviewing should be considered as work-related activity. Fairness should also be considered on a global level. Not only researchers obtaining various research grants (mostly from rich countries) should have a fair opportunity to publish their research results. Any researcher should have the fair publish to publish her/his research results under a high quality peer review process. Vice versa also research results users (e.g. other researchers, enterprises involved in applied research, the interested public) should have fair access to all research results that where created thanks to public funding.

2) The opportunity to publish high quality research results fulfilling all scientific standards and scientific ethical principles should be guaranteed to all researchers. Currently researchers often depend on the subjective decision-making by others (often anonymous persons) during peer review processes that are assessing research work. Sometimes researchers manage to publish the same article in another journal after having being rejected in previous peer-review in other scientific periodicals. How can it happen that in some journals (reviews) you can be rejected and in others for the same work you can be accepted? Usually there is also no chance to appeal to the decision of a peer-review evaluation and there is no real legal tool of how justice could be served in case that ethical peer review principles have been breached.

3) A very important element of the academic publication process is the assurance of high quality research results that might be used by others for further research or in practical life. Usually the peer review process should check and evaluate the quality of research results 
and its methodology. However we can see that the current system is not the best and that there are a lot of weak points of the review process of. The Sokal affair showed the weakness of review process, even in well-established journals (a physics professor published a pseudoscientific article in Social Text, an academic journal of postmodern philosophical studies; Sokal 1996, 62-64). The Bogdanov affair showed weakness of the review process in prestigious journals in the life sciences (Baez 2010). The unpaid review work of the peer reviewers and the sometimes lax work of editors and publishers are the main causes of the bleak contemporary situation. This state should be changed.

4) Fast dissemination of high quality results is also an extremely important element of the current academic world. Unfortunately, the peer-review process often takes a long time (often several months or sometimes even years) to evaluate the submitted articles. One of the factors of this slowness is the lack of reviewers who are able and willing to quickly review a given text. Reviewers are not motivated because if they are not paid, then specific unpaid work is not a priority. It is for them rather an extra job. For editors it is sometimes difficult to find somebody to review a submission. A faster pre-publication process would contribute to faster progress in research and development.

5) The price of journal subscriptions poses a severe limit. A lot of public money is spent by research institutions and researchers for this activity. Why should a library or individual researcher have to pay for access to research results that were created thanks to public funding? The legal and democratic principle of free access to the information that is produced and held by public institution, whose activities are usually (co-)funded by public budgets, should be respected. In the case of some journals, costs arise for researchers in the peer review process: they have to pay a submission fee (an example is the journal Technology, Transfer and Entrepreneurship published by Bentham Science Publishers) and these journals claim that these fees cover the costs for peer review process (even though the reviewers are not paid for their work).

\section{Open Access and Freedom of Information}

Freedom of information is in the European Union regulated mostly by national legislation. Each member state has its own legal rules, however these are based upon the principles described in the Council of Europe recommendations (Recommendation No. R (2002) 2 on access to official documents).

There is also a secondary legislation of the EU dealing with public information legislation. There are several EU directives in this legal field. Some of them are based on the Aarhus Convention that was adopted in 1998. This convention established a number of rights vis-àvis to the environment, including rights on access to information. This can include for example information on the state of the environment, but also on policies or measures taken, or on the state of human health and safety where this can be influenced by the state of the environment. According to this convention public authorities are obliged to actively disseminate environmental information that they possess. Even though it is not explicitly codified, results of public environmental research should be under the regulation of this legislation.

The following main EU legislative acts are based on the Aarhus Convention that regulates the free access to information created or supported by public institutions:

1) Directive 96/9/EC of 11 March 1996 on the legal protection of databases. According to the directive, there is copyright protection of databases, however this protection does not apply in most jurisdictions to mere facts or physical data as they are not original and in the public domain.

2) Directive 2003/98/EC of 17 November 2003 (and its amendment from 26 June 2013) on the re-use of public sector information (PSI). It is built around two main elements: Transparency and fair competition. The directive establishes minimum rules for the re-use of PSI throughout the European Union. Member States are also encouraged to go beyond these minimum rules and to adopt open data policies, allowing a broad use of documents held by public sector bodies. 
3) Directive 2007/2/EC of the European Parliament and of the Council, 14 March 2007, established an Infrastructure for Spatial Information in the European Community (further INSPIRE). The INSPIRE directive aims at creating a European Union (EU) spatial data infrastructure (SID). This SID regulates data sharing of environmental spatial information among public sector organizations and better facilitation of public access to spatial information across European Union.

There are also derived principles of international custom law in favour of free access to public information. These principles were generally identified by the Helsinki act: "In the field of human rights and fundamental freedoms, the participating States will act in conformity with the purposes and principles of the Charter of the United Nations and with the Universal Declaration of Human Rights. They will also fulfil their obligations as set forth in the international declarations and agreements in this field, including inter alia the International Covenants on Human Rights, by which they may be bound". The Universal Declaration of Human Rights, even though signed as non-binding document on 10 December 1948, became international custom. It specifies in article 19 a provision that might be interpreted in favour of free access to public information and open access publications: According to article 19, "[e]veryone has the right to freedom of opinion and expression; this right includes freedom to hold opinions without interference and to seek, receive and impart information and ideas through any media and regardless of frontiers".

Free access to the documents of the main European institutions is guaranteed by special Regulation (EC) No 1049/2001 of the European Parliament and of the Council (30 May 2001) regarding public access to European Parliament, Council and Commission documents.

As you can see from the previously mentioned legislative acts, there is a strong basis for the active publication of the scientific results gained from the research carried out by public institutions or just (co-)financed by public funding and realised by private institutions. Most current open access policies do not entirely follow the freedom of information principles. For example publication embargos of some scientific journals do not respect the legal task of public institutions to publish information without any time delay.

\section{Open Access and Competition Law}

We want to point out one aspect of EU competition law: The protection of entrepreneurship from unlawful public aid is primarily regulated by EU legal provisions that are part of the EU primary law - the Treaty on the Functioning of the European Union. The first paragraph of article 107 of the Treaty defines public aid as "any aid granted by a Member State or through State resources in any form whatsoever which distorts or threatens to distort competition by favouring certain undertakings or the production of certain goods shall, in so far as it affects trade between Member States, be incompatible with the internal market". Legal provisions of the Treaty and the EU secondary legislation define legal exemptions from lawful public aid. This definition of public aid can be applied to the current system of academic publishing, which does not form a legal exemption.

Why should just a few publishers be supported by public money (by subscription of public academic libraries, by the free work of reviewers having full time jobs at public institutions and in some cases by publication feeds funded by public money)? A significant share of the big publishers' income comes from public budgets. This distorts the market because it is extremely difficult to launch new scientific periodicals that are financially and economically viable and can compete with the major players in publishing. The current situation might from this perspective be considered as a breach of general public aid rules. The authors of this analysis cannot see a suitable legal exemption that "legalises" the current state.

\section{A New Model of Open Access}

How to tackle the challenges that the currently dominant publication model is facing? How can we reach a new vision of publishing? How can we fulfil the legal rules of freedom of 
information legislation and fair economic competition? How should a new publication model work and look like?

In order to fulfil the main five elements of an ideal open access model it would be very useful to have a strong supportive coordinator who would be able to organise a fair peer review process (evaluation) and free access publications. The role of this coordinator might be realised by a strong research funding body such as the European Commission that funds research programmes such as Horizon 2020. This influential body could, via research projects funded by EU budget, reform (or at least significantly influence and improve) the whole system of academic evaluations, scientometrics, academic publishing and higher education. If a specific amount money were allocated for open access publications in research projects, this money could be used by the European Commission (or an "open access coordinator", bellow in the text "coordinator") for peer review process and funding free open access publications.

This means that in the suggested model beneficiaries of research grants would be obliged to submit their research papers that stem from such a project to a peer review organised by the coordinator (this body would organise the peer review process in coordination with evaluators as is currently done in the evaluation of EU project applications). The coordinator would make sure that reviewers are remunerated. This evaluation process could also implement an administrative appeal processes under judicial control.

If the paper would fulfil all evaluation criteria, it would be openly published immediately on the coordinator's online publishing platform. The coordinator would also be responsible for scientometrics (e.g. the monitoring of the published papers' citations). Further reuse of the published results (even commercial) might be possible. Authors of the papers that were created thanks to non-EU budgets might be able to participate in publishing works on the coordinator's publishing platform too. However, they would have to cover all financial expenses for the review process and publication (as it is the case in in some open access journals now). Other funding bodies (e.g. national funding institutions, companies supporting research grants) might join this new open access activity and share costs with the coordinator. Grant holders of these partners would have the opportunity (and sometimes perhaps obligation) to publish peer-reviewed research articles on the coordinator's publishing platform

The coordinator would also publish the peer reviews so that reviewing is transparent. This new open access platform could be interlinked with various web portals, e.g. the Open Education Europa portal that the European Commission launched in September 2013. Such interlink would contribute to achieving a better sharing of knowledge and the spread of the latest research results approved by a high quality review process.

Current commercial publishers would still have the opportunity to publish articles that are funded by non-public resources. And if the coordinator decided to outsource this new open access publication activity, publishers would be given the opportunity to participate in a public procurement competition to carry out this publication service under a public service obligation.

\section{Conclusion}

There are complex legal, economic and other issues that the academic publishing world is facing. Reforms of this system are needed. This paper suggested a new public-service model of open access. Of course further analyses of the implications of the proposed "new open access" model are needed. It is however clear that there are ways how open access can meet all the expectations of different stakeholders, such as (researchers, public funding bodies, publishers, students and others.

\section{References}

Baez, John. 2010. The Bogdanoff Affair. http://math.ucr.edu/home/baez/bogdanoff/ (accessed on October 13, 2013). 
Council of Europe: Recommondation Rec (2002) 2. Strasbourg: 2003 http://www.accessinfo.org/documents/Access_Docs/Thinking/Principles/CofE_Rec_20022_access to docs.pdf http://math.ucr.edu/home/baez/bogdanoff/ (accessed on October 20, 2013).

Dahl, Robert A., 1989. Democracy and its Critics. New Heaven and London: Yale University Press.

European Commission: Open Education Europa. Brussels: EC. http://www.openeducationeuropa.eu/ (accessed on October 20, 2013).

Myška, Matěj. 2013. Open Data \& Open Definition. Brno: Masaryk University. http://prezi.com/czptmapumhph/open-data-open-definition/ (accessed on October 13, 2013).

Sokal, Alan. 1996. A Physicist Experiments with Cultural Studies. Lingua Franca May/June: 62-64 http://www.physics.nyu.edu/sokal/lingua franca v4.ascii (accessed on October 13, 2013).

The European Parliament and the Council of the European Union. 1996. Directive 96/9/EC of 11 March 1996 on the legal protection of databases. Luxembourg: Official Journal http://eurlex.europa.eu/LexUriServ/LexUriServ.do?uri=CELEX:31996L0009:EN:HTML (accessed on October 20, 2013).

The European Parliament and the Council of the European Union. 2003. Regulation (EC) No 1049/2001 of the European Parliament and of the Council of 30 May 2001 regarding public access to European Parliament, Council and Commission documents. Luxembourg: Official Journal http://eur-lex.europa.eu/LexUriServ/LexUriServ.do?uri=CELEX:32001R1049:EN:HTML (accessed on October 20, 2013).

The European Parliament and the Council of the European Union. 2003. Directive 2003/98/EC of 17 November 2003 on the re-use of public sector information. Luxembourg: Official Journal http://eurlex.europa.eu/LexUriServ/LexUriServ.do?uri=OJ:L:2003:345:0090:0096:EN:PDF and its amendment from 26 June 2013 http://eurlex.europa.eu/LexUriServ/LexUriServ.do?uri=OJ:L:2013:175:0001:0008:EN:PDF (accessed on October 20, 2013).

The European Parliament and the Council of the European Union, 2007. Directive 2007/2/EC of the European Parliament and of the Council of 14 March 2007 establishing an Infrastructure for Spatial Information in the European Community (INSPIRE). Luxembourg: Official Journal http://eurlex.europa.eu/LexUriServ/LexUriServ.do?uri=OJ:L:2007:108:0001:0014:EN:PDF (accessed on October 20, 2013).

The United Nations, 1948. The Universal Declaration of Human Rights. New York: UN Publications http://www.un.org/en/documents/udhr/index.shtml\#a19 (accessed on October 20, 2013).

Treaty on the Functioning of the European Union. 2009. Luxembourg: Official Journal http://eurlex.europa.eu/LexUriServ/LexUriServ.do?uri=OJ:C:2012:326:0047:0200:EN:PDF (accessed on October 21, 2013).

University of Minnesota Human Rights Library. 2009. The Final Act of the Conference on Security and Cooperation in Europe, Aug. 1, 1975, 14 I.L.M. 1292 (Helsinki Declaration). Minneapolis, http://www1.umn.edu/humanrts/osce/basics/finact75.htm (accessed on October 20, 2013).

\section{About the Authors}

Jiři Kolman is scientific secretary of the Global Change Research Centre at the Academy of Sciences of the Czech Republic (CzechGlobe). He is mainly responsible for scientific management, scientific evaluations and scientometrics. Jiři Kolman is also studying in the Ph.D. programme of EU law at Masaryk University's Faculty of Law. His main research is on free access to the EU institutions' information.

Petr Kolman is assistant professor at Masaryk University (Faculty of Law, Department of Administrative Studies and Administrative Law). His main research is on administrative law and especially the free access to information legislation. 